\title{
New Records of Jumping Plant-lice from Hungary (Hemiptera: Psylloidea)
}

\author{
G. RIPKA ${ }^{1 *}$ and GY. CSÓKA ${ }^{2}$ \\ ${ }^{1}$ National Food Chain Safety Office, Directorate of Plant Protection, \\ Soil Conservation and Agri-environment, Department of Pest Management Development and Coordination, \\ Budaörsi út 141-145, H-1118 Budapest, Hungary \\ ${ }^{2}$ National Agricultural Research and Innovation Centre, Forest Research Institute, \\ Department of Forest Protection, Hegyalja út 18, H-3232 Mátrafüred, Hungary
}

(Received: 9 February 2016; accepted: 28 March 2016)

\begin{abstract}
Authors made regular insect collections between 2008 and 2015 especially on ornamental trees and shrubs, also on herbs, on streets, parks, in city greenery, forests, botanical gardens and private gardens, in various localities of Hungary. Trioza ilicina (De Stefani Perez), Ctenarytaina eucalypti (Maskell) and Ctenarytaina peregrina Hodkinson are reported for the first time in Hungary. New host, locality and habitat data are given.
\end{abstract}

Keywords: Triozidae, Aphalaridae, Quercus, Chenopodium, Urtica, Eucalyptus, new host, Hungary.

Psylloids or jumping plant-lice are a group of highly host specific, sternorrhynchous insects (Burckhardt et al., 2013). They generally develop on woody dicotyledons. So far, a total of 76 psyllid species have been recorded in the territory of Hungary (Ripka, 2008b, 2009). Faunistic data of Horváth (1886, 1897), Hudák and Pénzes (2005), Rédei and Pénzes (2006), Ripka (1997, 2003), Ripka and Kiss (2007, 2008) and Haltrich et al. (2010) verify the richness of the Hungarian fauna living on vascular plants.

\section{Materials and Methods}

In continuation of the psyllid also aphid and mite survey on ornamental trees and shrubs of streets, squares, parks, botanical gardens, private gardens, forests and green-belt in all districts of Budapest city and in other localities of Hungary new samples have also been taken from the plants showing the symptoms of mite, aphid and psyllid feeding.

Plant samples from different plants were collected in plastic bags during the growing season between 2008 and 2015. All the plant material was examined with binocular stereomicroscope (Zeiss Stemi 2000-C) (upper and lower surfaces of the leaves, petioles, buds, bark, flowers, galls, etc.). The immatures of psyllids found on the plant samples were put directly into lactic acid. After clearing the specimens in lactic acid (for 2-4 weeks at room temperature to the desired extent), they were placed into Keifer's F-medium (Keifer,

\footnotetext{
* Corresponding author; e-mail: RipkaG@nebih.gov.hu
} 
1975). The slide preparations were dried (for 2-4 weeks) at room temperature, and then sealed with commercial nail varnish (Upton, 1991). Specimens were examined with a phase-contrast microscope (Nikon Eclipse E 600). Morphological terminology mostly follows Ossiannilsson (1992). For determination the keys of Hodkinson and White (1979), White and Hodkinson (1981) and Ossiannilsson (1992) also other available reports were used.

The scientific name of host plants is used according to Király (2009).

\section{Results}

Fam. Triozidae

Trioza chenopodii Reuter, 1876

Geographical distribution - It is a Palaearctic species, reported from Austria, former Czechoslovakia, France, Germany, Great Britain, Greece, Denmark, Finland, Norway, Italy, Cyprus, Poland, Romania, Slovenia, Ukraine, Russia, Spain, Sweden, Syria, Georgia, Kazakhstan, Turkmenia, Pakistan, Iran, Jordan, Israel, Lebanon, Iraq, Kuwait, Oman, India, Japan, Korea, Mongolia, Canada, Chile, California, USA (Ossiannilsson, 1992; Burckhardt, 2007; Burckhardt and Lauterer, 1993; Ouvrard, 2010; Percy et al., 2012).

Host plants - The immatures feed and develop on Chenopodium L., Atriplex L., Halimione portulacoides (L.) Aellen, Spinacia oleracea L., Beta vulgaris L. (all fam. Chenopodiaceae) (Lauterer and Šrámková, 1983; Ossiannilsson, 1992; Ouvrard, 2010). It is a dimorphic species, having a long wing summer form (f. aestivalis) and a short wing autumn-winter form (f. autumnalis).

Immatures - The fifth instar nymph is pale yellow, f. aestivalis without, f. autumnalis with brownish pattern. Body length 1.51-1.69 mm. Dorsum of head, wingpads and abdomen with scattered sectasetae (Ossiannilsson, 1992).

Adult - Extremely variable in colour. Seasonally dimorphic: f. autumnalis darker and with shorter and broader forewings, f. aestivalis with forewing normal in length. Body length: f. aestivalis male: $2.10-2.71 \mathrm{~mm}$, female: $2.48-3.05 \mathrm{~mm}$, f. autumnalis male: 1.81-2.10 mm, female: 1.90-2.14 mm (Ossiannilsson, 1992).

Life cycle - In Great Britain it has two generations (Hodkinson and White, 1979). According to Ossiannilsson (1992) in Scandinavia, the species probably bivoltine, and the hibernation takes place in adult stage. No association with conifers has been observed in this species. T. chenopodii causes no deformations on the hosts (Percy et al., 2012).

Hungarian data - The yellow larvae with red eyes were collected from the lower side of the leaves of goosefoot or lamb's quarters, Chenopodium album L. (Fam. Chenopodiaceae), no damage was observed. Some nymphs were found in pod-like, yellowish pseudogalls formed by rolling leaves upwards, which were caused by Hayhurstia atriplicis (L.) (Hemiptera: Aphididae).

Locality and date - Maglód, Pest county, in a private garden, 10 September 2014, coll. G. Ripka. 
Remarks - In Hungary, Horváth $(1886,1897)$ recorded it at Gellérthegy (Budapest), Nyíregyháza (Szabolcs-Szatmár-Bereg county), Simontornya (Tolna county), and several other localities which that time were in the territory of Austro-Hungarian Monarchy, e.g. Beregszász (at present Beregovo, Ukraine), Magyarbél, Modor, Szentgyörgy (all three villages currently Slovakia). He suspected that this was a rare species.

\section{Trioza urticae (Linnaeus, 1758)}

Geographical distribution - It is a Palearctic species, reported from Austria, Belgium, Belarus, Bulgaria, Croatia, Czech Republic, France, Germany, Great Britain, Ireland, Denmark, Finland, Norway, Sweden, Lithuania, Italy, Malta, Greece, Cyprus, Moldova, Poland, Romania, Slovenia, Slovakia, Ukraine, Russia, Spain, Algeria, Lebanon, Turkey, Iran, Afghanistan, India, China, Japan, Mongolia, Tadzhikistan (Burckhardt and Lauterer, 1993; Burckhardt and Önuçar, 1993; Burckhardt, 2007; Ouvrard, 2010).

Host plants - The immatures and adults feed and develop on Urtica dioica L., Urtica urens L. and other Urtica species (fam. Urticaceae) (Ossiannilsson, 1992; Ouvrard, 2010). Shelter plants: Picea A. Dietr. (fam. Pinaceae) (Ouvrard, 2010).

Immatures - The fifth instar nymph is orange or brownish with greyish spots. Body length 1.55-1.90 mm (Ossiannilsson, 1992). Dorsal surface of body and wing-pads with sparsely arranged truncate sectasetae of similar length to those on the forewing-pad margin (White and Hodkinson 1981; Ossiannilsson, 1992).

Adult - General body colouration highly variable. Young specimens yellow or green, with brown and cream markings. Older specimens cream, with brown and black markings (Hodkinson and White, 1979). Central part of prothorax whitish, abdomen brownish, segment borders and connecting membranes yellow or greenish. Forewing colourless, body length of male: 2.95-3.43 mm, of female: 3.29-3.52 mm (Ossiannilsson, 1992).

Life cycle - According to Hodkinson and White (1979) it has four generations. The hibernation takes place in adult stage (Horváth, 1886; Hodkinson and White, 1979). The adults overwinter abundantly on conifers but individuals can be found in grass tussocks at the base of the dead host plant, $U$. dioica (Hodkinson and White, 1979). T. urticae causes bladder-like deformations on the host (Ossiannilsson, 1992).

Hungarian data - The yellow and greenish brown nymphs, and adults were collected from the lower side of the leaves and on young twigs of stinging nettle, Urtica dioica, no damage was observed. This species co-occurred with Microlophium carnosum (Buckton) (Hemiptera: Aphididae: Macrosiphini) (Ripka, 2008a).

Locality and date - Mesteri, Vas county, in a private garden, 1 June 2008, coll. G. Ripka.

Remarks - In spite of Fauna Europaea database, in which T. urticae is absent from Hungary, the species has been known from a long time in Hungary. Horváth (1886, 1897) stated that it was a frequent species in the territory of Austro-Hungarian Monarchy [(recorded in Buda (Budapest), Gödöllö, Farkasd (both Pest county), Simontornya (Tolna county), Pétervárad (at present Serbia), Csáktornya (currently Croatia), Gerencsér (Slovakia), etc.)]. Since Horváth's works only one book has been known in which T. urticae was mentioned, but without host and locality data (Soós, 1969). 
Trioza remota Foerster, 1848

Geographical distribution - It is an European species, reported from Austria, Belarus, Czech Republic, Denmark, Finland, Germany, Great Britain, Greece, Ireland, Lithuania, Norway, Poland, Romania, Slovakia, Slovenia, Sweden, Switzerland, Ukraine, Algeria, Lebanon, Georgia, Turkey, Iran, Japan (Ossiannilsson, 1992; Burckhardt, 2007; Ouvrard, 2010).

Host plants - Quercus robur L., Quercus petraea (Matt.) Liebl., Quercus pubescens Willd., Quercus L. (all fam. Fagaceae) (Conci and Tamanini, 1985; Ouvrard, 2010), Quercus rubra L. (Merrifield and Merrifileld, 2012 cit. Ouvrard, 2010 as questionable), Quercus glauca Thunb. (Yukava and Masuda 1996 cit. Ouvrard, 2010 as to be confirmed). According to Conci and Tamanini (1985) nymphs from this evergreen oak ( $Q$. glauca) in Japan, probably is not either Trioza remota or Trioza ilicina. Shelter plants: Abies Mill., Pinus L. (both fam. Pinaceae) (Ouvrard, 2010).

Immatures - Body length of fifth instar nymph 1.71-2.10 mm. Forewing-pad less than $1.02 \mathrm{~mm}$ long (White and Hodkinson, 1981). Colour greenish-white, dirty whitish or brownish-yellow. They live in small pit on the underside of the leaves (Ossiannilsson, 1992).

Adult - The young specimens yellow or orange-coloured, while the older individuals with diffuse brown or blackish-brown confluent markings that vary in extent. Forewings colourless, veins brownish. Antennae are dark in all except the first three segments. Legs yellow or orange with fuscous markings. Length of males 3.33-3.62 mm, of females 3.57-4.00 mm (Ossiannilsson, 1992).

Life cycle - According to Hodkinson and White (1979) it has one generation. Adults overwinter on conifers (Ossiannilsson, 1992).

Hungarian data - The eggs, yellowish larvae and nymphs were collected from the lower side of the leaves of Quercus robur, Quercus petraea, Quercus pubescens and Quercus rubra. Around the egg and nymph, small light green, then yellowish green galls on the upper side, and small concave surface, a small pit on the lower side of the leaves.

Locality and date - English oak, Quercus robur: Murarátka, Zala county, at edge of an old floodplain oak forest, 15 September 2015, coll. Gy. Csóka.

Sessile oak, Quercus petraea: Mátraháza, Heves county, in the margin of an old oak forest, 17 July 2010, coll. Gy. Csóka; Vászoly, Veszprém county, on a middle age tree in a wooded pasture like habitat, 21 August 2010, coll. Gy. Csóka.

Downy oak, Quercus pubescens: Mátrafüred, Heves county, in a rather open forest habitat at a hill top, 10 September 2014, coll. Gy. Csóka.

Northern red oak, Quercus rubra: Baktalórántháza, Szabolcs-Szatmár-Bereg county, in a middle age planted stand, 21 October 2015, coll. Gy. Csóka.

Remarks - In Hungary, Horváth $(1886,1897)$ recorded it Buda, Rákospalota (both localities Budapest), Farkasd, Göd (both Pest county), Felsőtárkány (Heves county), Badacsony (Veszprém county), Simontornya (Tolna county), Debrecen (Hajdú-Bihar county), and several other localities which that time belonged to the Austro-Hungarian Monarchy, e.g. Czéke (currently Slovakia), Szécspolyánka (Slovakia), Tasnád (Romania), Marilla (Romania), Varasd-Teplic (Croatia) and Podsused (Croatia). He collected the overwintered adults between April and May, and the adults of summer generation during September and October. Trioza remota has been first recorded from any North American red oaks. 
Trioza ilicina (De Stefani Perez, 1901)

Geographical distribution - It is a Mediterranean species, reported from Italy, Sardinia, Sicily, Spain, France and Balearic Islands (Conci and Tamanini, 1985; Burckhardt, 2007).

Host plants - Holm oak or holly oak, Quercus ilex L. Early data (1910, 1913, 1914, 1919) from cork oak, Quercus suber L. from France, Corsica and Algeria are doubtful determinations according to Conci and Tamanini (1985).

Immatures $-T$. ilicina possesses numerous, strong lanceolate setae dorsally, in constant position (Conci and Tamanini, 1985). T. remota lacks lanceolate setae, which are replaced by short and thin single setae. The marginal ringed sectasetae in T. ilicina are longer, almost pointed, less close spaced and less numerous than in T. remota. The latter has distictly truncate sectasetae. Nymphs of T. ilicina live in small pit galls on the underside of the leaves (Conci and Tamanini, 1985; Hodkinson, 2009).

Adult - The young specimens light yellow green. The more mature males are pale brown, the females brown. Forewings hyalin, without pattern. Antennae are light brown. Length of males 3.0-3.4 mm, of females 3.5-4.0 mm (Conci and Tamanini, 1985).

Life cycle - According to Conci and Tamanini (1985) it has one generation. Larvae overwinter on the leaves of holm oak (Conci and Tamanini, 1985; Hodkinson, 2009). Adults appear in early spring.

Hungarian data - The eggs, larvae and nymphs were collected from the lower side of the leaves of Quercus cerris L. The young larvae are shiny yellow, dirty yellow with red eyes, while the dorsal side of developed nymph is turquoise and ventrally yellowish. Around the egg and nymph, small light green, then yellowish green, later reddish round galls on the upper side, $1-1.5 \mathrm{~mm}$ in diameter, and small concave surface, a small pit on the lower side of the leaves.

Locality and date - Turkey oak, Quercus cerris: Vászoly, Veszprém county, in seminatural habitat, 21 August 2010, 13 June 2011, 17 July 2011, 15 August 2011, 16 September 2012, coll. G. Ripka; Cserépfalu, Borsod-Abaúj-Zemplén county, in a wooded pasture, 9 September 2015, coll. Gy. Csóka; Mátrafüred, Heves county, in a middle age open forest, 14 September 2015, coll. Gy. Csóka.

Remarks - Horváth $(1886,1897)$ did not record it from the Austro-Hungarian Monarchy. This species is new for the Hungarian fauna. The new Hungarian locations listed above are many hundred kms further North from the native range of T. ilicis has been known so far. Therefore these records can be considered as results of a significant northward move of the species. Quercus cerris has not yet been recorded as host of the species.

Fam. Aphalaridae

Ctenarytaina eucalypti (Maskell, 1890)

Geographical distribution - Australia, New Zealand, Brazil, Bolivia, Chile, Colombia, France, Germany, Great Britain, Ireland, Italy, Portugal, South Africa, Spain, Sri Lanka, Switzerland, California, USA (Percy et al., 2012).

Host plants - According to Ouvrard (2010) it is known from 13 species of genus Eucalyptus, i.e. E. benthami Maiden et Cambage, E. bicostata Maiden, Blakely et Sim- 
monds, E. cinerea F. Muell. ex Benth., E. cordata Labill., E. dunnii Maiden, E. globulus Labill., E. guni Hook. f., E. nicholii Maiden et Blakely, E. nitens Maiden, E. parviflora F. Muell., E. perriniana F. Muell. ex Rodway, E. pulverulenta Sims.

Immatures - Body length 1.18-1.38 mm. Head, thorax, and abdomen sclerites, wing-pads, antenna and legs yellow-brown to orange-brown, membranes colourless (pres. mat.) (White and Hodkinson, 1981).

Final instar larva with lateral abdominal pore fields extending only part way along the margin of the abdomen. Outer margin of forewing pad broadly rounded (Hodkinson, 2007). The body is yellowish, but the dorsal derm consists of blue-black sclerites over most of the body. This tends to take on a greyish cast because the white flocculent wax secretions are produced over the body by glands on the dorsal and lateral surfaces of the abdomen.

Adult - These are approximately $2 \mathrm{~mm}$ long from the head to the wing tips. The adult is green to tan, but with dark-brown to black head and thorax dorsums. Length of antennae more than 0.96 times head width. Forewing more oval shaped, with a broadly rounded apex (Hodkinson, 2007). Some of the morphological characteristics that separate the genus Ctenarytaina from other psyllid genera include: metacoxal meracanthi not elongated; mesotibial pectens (a comb-like arrangement of setae) occur at the distal ends of the mesotibiae; and the apical cell of the forewing (medial cell) is short, usually shorter than the cubital vein.

Egg - These are laid singly and randomly on juvenile shoots, in crevices along the leaf petioles, usually perpendicular to the plant surface. They are spindle-shaped, yellow or cream, and are slightly less than $1 \mathrm{~mm}$ long.

Life cycle - According to Hodkinson (2009) it has up to 8 generations. Egg, larva and adult overwinter on the shoots of host plant.

Hungarian data - The immatures and adults were collected from juvenile shoot tips and the lower side of the leaves of Dunn's white gum, Eucalyptus dunnii Maiden (Fam. Myrtaceae), no damage was observed. The pot plants were imported from the UK.

Locality and date - Budapest Zoo, Budapest XIV district, greenhouse, 8 October 2014, coll. B. Szántó.

Remarks - Among the spodyliaspidines, the genus Ctenarytaina is one of the largest psyllid genera, associated mainly with Myrtaceae, colonising and damaging eucalypt hosts. The 15 known species are native to Australia, New Zealand, the Pacific, Taiwan and China. Ctenarytaina eucalypti and Ctenarytaina spatulata Taylor have been introduced into other countries, and became the important pests of cultivated eucalypts (Hollis, 2004; Burckhardt et al., 2013).

Ctenarytaina peregrina Hodkinson, 2007

Geographical distribution - It is known from the UK, Ireland, Germany, France and Italy (Hodkinson, 2007; Ouvrard, 2010; Burckhardt et al., 2013).

Host plants - The species was described from Eucalyptus parvula L.A.S. Johnson et K.D. Hill (Fam. Myrtaceae) in the UK and Ireland (Hodkinson, 2007). E. parvula is 
an ornamental eucalypt in Europe, but a rare and threatened species in its native range in New South Wales, Australia.

Immatures - Fifth instar larva with conspicuous lateral abdominal pore fields extending backwards alongside each of the 3 lateral subrectangular abdominal plates on the ventral surface of the abdomen. Outer anterior margin of forewing pad angled, the antennae relatively shorter than that of $C$. eucalypti (Hodkinson, 2007).

Adult - Colour generally yellowish to orange throughout in newly hatched specimens. Dorsal surface of head and thorax becoming dark blue-grey to greyish-black in older specimens, often with waxy sheen in live specimens. Terminalia and dorsal scerites of abdomen becoming brown, particularly in the mature female. Length of antennae less than 0.92 times head width. Forewing somewhat rhomboidal in shape, with a narrowly rounded apex, semi-opaque, dirty whitish or whitish yellow, with veins concolorous or slightly darker (Hodkinson, 2007).

Life cycle - It has multiple generations per year. Egg, larva and adult overwinter on the shoots of host plant (Hodkinson, 2009).

Hungarian data - The immatures were collected from the shoot tips of Dunn's white gum, Eucalyptus dunnii, no damage was observed. The pot plants were imported from the UK.

Locality and date - Budapest Zoo, Budapest XIV district, greenhouse, 8 October 2014, coll. B. Szántó.

Hungarian data - The immatures and adults were collected from the lower side of the leaves and shoot tips of Black gum, Eucalyptus aggregata H. Deane et Maiden (Fam. Myrtaceae), no damage was observed. The pot plants were imported from the UK.

Locality and date - Budapest Zoo, Budapest XIV district, greenhouse, 4 November 2014, coll. B. Szántó.

\section{Acknowledgements}

The authors would like to thank Dr Daniel Burckhardt (Naturhistorisches Museum, Basel, Switzerland) for the identification of Ctenarytaina eucalypti (Maskell) and C. peregrina Hodkinson, and Béla Szántó (Budapest Zoo, Hungary) for providing the leaf samples taken from the gum species.

\section{Literature}

Burckhardt, D. (2007): Fauna Europaea: Psylloidea. Fauna Europaea version 1.3, Taxon Details. Available from http://www.faunaeur.org [accessed 5 September 2015]

Burckhardt, D. and Lauterer, P. (1993): The jumping plant-lice of Iran (Homoptera, Psylloidea). Revue suisse de Zoologie 100, 829-898.

Burckhardt, D. and Önuçar, A. (1993): A review of Turkish jumping plant-lice (Homoptera, Psylloidea). Revue suisse de Zoologie 100, 547-574.

Burckhardt, D., Farnier, K., Queiroz, D. L., Taylor, G. S. and Steinbauer, M. J. (2013): Ctenarytaina bipartita sp. n. (Hemiptera, Psylloidea), a new eucalypt psyllid from Southeast Australia. Zootaxa 3613 6, 589-596. Available from http://dx.doi.org/10.11646/zootaxa.3613.6.5 [accessed 26 May 2015].

Conci, C. and Tamanini, L. (1985): Redescription of Trioza ilicina (De Stefani Perez, 1901) comb. n., from Quercus ilex (Homoptera Psylloidea). Boll. Lab. Entomol. Agrar. Filippo Silvestri, Portici 42, 33-46. 
Haltrich, A., Rédei, D., Pénzes, B. and Vétek, G. (2010): A babér-levélbolha (Trioza alacris Flor, 1861) (Sternorrhyncha: Triozidae) megjelenése Magyarországon. (First occurrence of bay sucker (Trioza alacris Flor, 1861) (Sternorrhyncha: Triozidae) in Hungary.) Növényvédelem 46, 365-369.

Hodkinson, I. D. (2007): A new introduced species of Ctenarytaina (Hemiptera: Psylloidea) damaging cultivated Eucalyptus parvula (= parvifolia) in Europe. Deutsche Entomologische Zeitschrift 54, $27-33$. Available from DOI: 10.1002/mmnd.200700002 [accessed 14 May 2015].

Hodkinson, I. D. (2009): Life cycle variation and adaptation in jumping plant lice (Insecta: Hemiptera: Psylloidea): a global synthesis. J. Natural History 43, 65-179. Available from DOI: 10.180/00222930802354167 [accessed 28 December 2015].

Hodkinson, I. D. and White, I. M. (1979): Homoptera Psylloidea. Handbk. Ident. Br. Ins. 2 (5 A). Royal Entom. Soc., London, pp. 1-98.

Hollis, D. (2004): Australian Psylloidea: Jumping Plantlice and Lerp Insects. Australian Biological Resources Study, Canberra, Australia. 216 p.

Horváth, G. (1886): A magyarországi Psyllidákról. (On the psyllids of Hungary.) Mathematikai és Természettudományi Közlemények 21, 292-320.

Horváth, G. (1897): Ordo. Hemiptera. In: A Magyar Birodalom Állatvilága (Fauna Regni Hungariae). III. Arthropoda. (Insecta. Hemiptera.) Királyi Magyar Természettudományi Társulat, Budapest, 72 p.

Hudák, K. and Pénzes, B. (2005): A hagymafélék legújabb kártevője a Trioza (Bactericera) nigricornis Förster. [The new pest of bulbs is Trioza (Bactericera) nigricornis Förster.] In: J. Horváth, A. Haltrich and J. Molnár (eds): [51st Plant Protection Days 2005. Abstracts of lectures and posters.] Magyar Agrártudományi Egyesület, Budapest, 3 p.

Keifer, H. H. (1975): Eriophyoidea Nalepa. In: L. R. Jeppson, H. H. Keifer and E. W. Baker (eds): Mites Injurious to Economic Plants. University of California Press, Berkeley, Los Angeles, London. pp. 327-533.

Király, G. (ed.) (2009): Új magyar füvészkönyv. Magyarország hajtásos növényei. Határozókulcsok. [New Hungarian Herbal. The Vascular Plants of Hungary. Identification key.] Aggteleki Nemzeti Park Igazgatóság, Jósvafö. 616 p.

Lauterer, P. and Šrámková, B. (1983): The psyllid Heterotrioza chenopodii (Reuter) (Homoptera, Triozidae), a new potential pest of beet plants. (Merule Heterotrioza chenopodii (Reuter) (Homoptera, Psylloidea) novy potenciální škudce repy.) Proc. of the IX Czechoslovak Plant Protection Conference in Brno, 30th August -1st September 1983. pp. 163-164.

Ossiannilsson, F. (1992): The Psylloidea (Homoptera) of Fennoscandia and Denmark. Fauna Entomologica Scandinavica, E. J. Brill, Leiden-New York-Köln, Vol. 26, 347 p.

Ouvrard, D. (2010): Psyl'list online database. Available from http://rameau.snv.jussieu.fr/cgi-bin/psyllesexplorer.pl?lang-en [accessed 16 December 2015].

Percy, D. A., Rung, A. and Hoddle, M. S. (2012): An annotated checklist of the psyllids of California (Hemiptera: Psylloidea). Zootaxa 3193, 1-27.

Rédei, D. and Pénzes, B. (2006): A selyemakác-levélbolha, Acizzia jamatonica (Kuwayama, 1908) (Sternorrhyncha: Psyllidae: Acizzinae) megjelenése Magyarországon. (First occurrence of Acizzia jamatonica (Kuwayama, 1908) (Sternorrhyncha: Psyllidae: Acizzinae) in Hungary.) Növényvédelem 42, 153-157.

Ripka, G. (1997): Újabb adatok a díszfa- és díszcserjefajok levélbolha-faunájának ismeretéhez (Homoptera, Psylloidea). (Recent data to the psyllid fauna of ornamental trees and shrubs of Hungary (Homoptera: Psylloidea).) Növényvédelem 33, 269-273.

Ripka, G. (2003): A Cacopsylla pulchella (Löw, 1877) (Homoptera: Psylloidea) megjelenése Magyarországon és kártétele közönséges júdásfán. (Occurrence of and damage caused by Cacopsylla pulchella (Löw, 1877) (Homoptera: Psylloidea) on judas tree in Hungary.) Növényvédelem 39, 453-456.

Ripka, G. (2008a): Checklist of the Aphidoidea and Phylloxeroidea of Hungary (Hemiptera: Sternorrhyncha). Folia Entomol. Hung. 69, 19-157.

Ripka, G. (2008b): Checklist of the Psylloidea of Hungary (Hemiptera: Sternorrhyncha). Acta Phytopath. et Entomol. Hung. 43, 121-142.

Ripka, G. (2009): Additional data to the aphid and psylloid fauna of Hungary (Hemiptera: Sternorrhyncha). Acta Phytopath. et Entomol. Hung. 44, 397-417. 
Ripka, G. and Kiss, B. (2007): Hazai parlagfü állományokban előforduló levélbolha-fajok (Hemiptera: Psylloidea). (Psyllid species (Hemiptera: Psylloidea) occurring on common ragweed in Hungary.) Növényvédelem 43, 63-66.

Ripka, G. and Kiss, B. (2008): További adatok a hazai parlagfüállományokban előforduló levélbolha-fajok (Hemiptera: Psylloidea) ismeretéhez. (Recent data to the knowledge on psyllid species (Hemiptera: Psylloidea) occurring on common ragweed in Hungary.) Növényvédelem 44, 257-261.

Soós, Á. (1969): Levélbolhák - Psyllina. [Psyllids - Psyllina.] In: L. Móczár (ed.): Állathatározó I. [Identification Guide to Animals. I.] Tankönyvkiadó, Budapest, pp. 335-337.

Upton, M. S. (1991): Methods for Collecting, Preserving, and Studying Insects and allied forms. The Australian Entomol. Soc., Brisbane. Misc. Publ. No. 3. v +86 p.

White, I. M. and Hodkinson, I. D. (1981): Psylloidea (Nymphal Stages) Hemiptera, Homoptera. Handbk. Ident. Br. Ins., 2 (5 B). Royal Entom. Soc., London, pp. 1-50. 